\title{
YAŞLILARDA YAĞSIZ VÜCUT KÜTLESİ VE EL KAVRAMA KUVVETİ İLIŞKİSI
}

\author{
Tuba MELEKOĞLU ${ }^{1}$, Birgül ARSLAN ${ }^{2}$ \\ ${ }^{1}$ Akdeniz Üniversitesi Spor Bilimleri Fakültesi, Antalya \\ ${ }^{2}$ Marmara Üniversitesi Sağlık Bilimleri Enstitüsü, İstanbul
}

Öz: El kavrama kuvveti genel kuvvetin, sağlığın ve yaşam kalitesinin göstergesi olan önemli bir bileşen olarak gösterilmektedir. Her ne kadar kas kütlesi ile kuvvet arasındaki ilişki iyi bilinse de özellikle yaşlanma süreçlerinde el kavrama kuvvetini etkileyen kas kütlesi veya cinsiyet gibi faktörleri incelemek ve el kavrama kuvvetine dair referans değerleri belirlemek önemlidir. Bu nedenle bu araştırmanın amacı cinsiyet, yaş ve yağsız vücut kütlesinin yaşlılarda el kavrama kuvvetini nasıl etkilediğini incelemektir. Bu amaçla araştırmaya, Dünya Sağlı Örgütü tarafindan yaşlı olarak sınıflandırılan 60- 80 yaş aralığındaki, elli kadın $(67.34 \pm 3.99$ yıl, $157.4 \pm 5.6 \mathrm{~cm}, 65.7 \pm$ $8.6 \mathrm{~kg})$ ve yaşa göre eşleştirilmiş elli erkek $(67.2 \pm 3.93 \mathrm{y} 1 \mathrm{l}, 170.4 \pm 6.8 \mathrm{~cm}, 75.0 \pm 11.0 \mathrm{~kg})$ dahil edilmiştir Araştırmaya katılan gönüllülerin vücut yă̆ yüzdesi ve yağsız vücut kütlesine yönelik ölçümler biyoelektrik empedans ölçüm cihazı ile, el kavrama kuvvetleri portatif el dinamometresi ile ölçülmüştür. Bu araştırma sonucunda erkeklerin rölatif ve salt el kavrama kuvvet değerleri kadınlara oranla anlamlı olarak daha yüksek tespit edilmiştir. Araştırma sonucunda yaş ile el kavrama kuvveti değerleri arasında anlamlı bir ilişki tespit edilmemiştir. Bununla birlikte kas kütlesi ile el kavrama kuvveti değerleri arasında pozitif yönde yüksek düzeyde anlamlı ilişki tespit edilmiştir. Araştırma sonuçlarımız doğrultusunda kas kütlesinin mümkün olduğunca korunmasıla birlikte yaşlılarda kuvvet kayıplarının daha az olacağı öngörülmektedir. Yaşlılarda yaşam kalitesinin arttırılması veya korunması için kas kütlesinin ve dolayısıyla kuvvetin korunması önerilmektedir. Ayrıca özellikle kadınlarda kas kütlesi kaybı dışında kas kuvvetini olumsuz etkileyen diğer fonksiyonel etkenlerin araştırılması önemlidir.

Anahtar Kelimeler: kas kütlesi, kuvvet, yaşlanma, el kavrama kuvveti, rölatif el kavrama kuvveti

\section{ASSOCIATION BETWEEN LEAN MASS AND HANDGRIP STRENGTH IN OLDER ADULTS}

\begin{abstract}
Handgrip strength is an essential component that reflects general strength, health and quality of life. Although the correlation of muscle mass and strength is known well, it is worth investigating the factors affecting hand grip strength such as lean mass or gender and determine the reference values especially in the aging processes. Therefore, the aim of this study is to investigate the effects of gender, age and lean mass on handgrip strength in the elderly. Fifty women $(67.34 \pm 3.99$ years, $157.4 \pm 5.6 \mathrm{~cm}, 65.7 \pm 8.6 \mathrm{~kg})$ and age-matched fifty men $(67.2 \pm$ 3.93 years, $170.4 \pm 6.8 \mathrm{~cm}, 75.0 \pm 11.0 \mathrm{~kg}$ ), aged between $60-80$ years and classified as elderly according to World Health Organization (WHO), were recruited in the study. Handgrip strength, height, body weight, lean mass and body fat percentages were measured. The study results show higher relative and absolute handgrip strength for men compared to women. Furthermore, no significant relationship was found between age and handgrip strength values. However, a significant positive correlation between muscle mass and handgrip strength was noted. The results of this study suggest that in case of maintaining muscle mass as much as possible, the strength loss may be minimized during the aging process. We conclude that to enhance or protect the quality of life in the elderly, muscle mass and therefore strength should be maintained. Further investigations are required to determine the other functional factors which lead to muscle strength loss especially in women.
\end{abstract}

Keywords: muscle mass, strength, aging, hand grip strength, relative handgrip strength 


\section{GíRIŞ}

Canlıların yaşlanması, fizyolojik fonksiyonlarda meydana gelen yıpranmanın hızlanması ve bunun sonucu olarak da ölüm riskinin zamanla artmasıdır. Yaşlanma tüm canlılar için kaçınılmaz bir durumdur. Bununla birlikte son 100 yıla bakıldığında insan ömrüne dair beklentinin arttığ görülmektedir. Öyle ki, 2050 yılında dünya çapında 1.5 milyardan fazla insanın 65 yaşından daha yaşı olacağı öngörülmektedir. Bu nedenle insan ömrünün uzamasına yönelik beklentiyle birlikte, yaşam kalitesinin arttırılması daha da değerli hale gelmiştir (Musalek ve Kirchengast, 2017).

Yaşlanma süreci, genellikle kas güçsüzlüğü ile ilişkili olan iskelet kası kütlesindeki azalma (sarkopeni) ile ifade edilir. Yaşlilıkla birlikte kas iskelet sisteminde değişiklikler olur. Sarkopeni sonucu denge kaybı, postural bozukluklar, yürüme hızında azalma gibi değişiklikler ortaya çıkabilir. Fizyolojik olarak devam eden bu süreç, yaşlanma döneminde kişilerin genetik faktörleri, fiziksel aktivite düzeyleri ve çevresel durumlarını içeren birçok faktörden etkilenmektedir. Genetik faktörler yaşlanma için değiştirilemez bir faktörken, fiziksel aktivite yaşlılığın geciktirilmesinde çok önemli bir etkendir (Karan, 2006; Yıldırım ve ark., 2012).

Yaşlanmayla gelişen iskelet kas kaybına neden olan faktör olarak kas protein sentezi ve yıkımı arasında oluşan dengesizlik gösterilmektedir. Yaşlanmaya bağlı gelişen spinal motor nöron kaybı, kas lifi sayısında ve büyüklüğünde azalmaya neden olmaktadır. Yaşlanmayla birlikte ilerleyen bu süreçlerde, iskelet kas kütlesi kaybına paralel olarak kas kuvveti de azalır. Kas kuvvetinin azalması da fonksiyonel kapasite kaybına, mekanik kas performansının düşmesine ve kronik metabolik hastalık oluşma riskinin artmasına neden olur. Bu etkileri azaltmak için birçok araştırmacı, besin alımı ve fiziksel aktivite gibi anabolik uyaranlara verilen kas protein sentetik tepkisine odaklanmakta ve sarkopeniyi önlemek veya tedavi etmek için beslenme, egzersiz ve iskelet kasının adaptasyon yeteneği arasındaki ilişkiyi araştırmaktadır (Koopman ve van Loon, 2009; Aagaard ve ark., 2010).

Yaşlılarda kas kütlesi ve kuvvetine yönelik araştırmalar ayrıca bu değişikliklerin sağlık ile olan ilişkisini incelemektedir. Bazı araştırmalarda (Choquette ve ark., 2010; Chen ve ark., 2013; Lawman ve ark., 2016) kas kuvveti azalmış olan yaşlılarda ölüm oranının daha yüksek olduğu bildirilmiştir. Yaşlılarda kas kütlesinin azalmasıyla paralel gelişen kas kuvveti kaybı fonksiyonel kısıtlılıklara yol açmakta ve yaşam kalitesini düşürmektedir. Hairi ve ark. (2010) yapmış oldukları çalışmada kas kuvvetinin, kas kütlesine göre, fonksiyonel kısıtlılık ve fiziksel yetersizlik üzerine daha büyük etkisi olduğunu göstermektedir. Her ne kadar yaşlanmayla birlikte kas kayıpları gerçekleşse de kas kuvvetinin korunması durumunda yaşam kalitesinin de korunabileceği bildirilmiştir. Bununla birlikte Newman ve ark. (2006) kuvvet ve ölüm oranı arasında yüksek ilişki bulmuşken, kas kütlesi ile ölüm oranı arasında bu düzeyde bir ilişki tespit edememişlerdir. Araştırmalarının sonucunda kas miktarına göre kas kalitesinin bir göstergesi olan kas kuvvetinin, ölüm riskini belirlemek üzere daha önemli bir değişken olduğunu bildirmişlerdir. Ayrıca araştırmalarında izokinetik quadriceps kuvveti ile el kavrama kuvveti arasındaki ilişkiyi incelemişler ve el kavrama kuvvetinin yeterli bir gösterge olduğu sonucuna varmışlardır.

Kavrama, günlük aktivitelerimizde önemli bir yere sahiptir. El kavrama kuvveti sporcular için genel kuvveti yansıtan önemli bir bileşen iken, sedanter ve yaşlı bireylerde yaşam kalitesinin bir göstergesidir. El kavrama kuvveti elin ve parmakların kuvvet oluşturabilme yeteneğini gösterir. Genellikle doktorlar üst ekstremitedeki yaralanma tedavilerinde, tedaviyi gözlemlemek adına el kavrama kuvvetini kullanırlar. Ayrıca sportif anlamda el kavrama 
kuvveti üst ekstremitedeki kuvvete dair performansı gözlemlemek adına kullanılmaktadır. Kolay uygulanabilir ve ekonomik olması bu ölçüm yönteminin daha fazla uygulanmasını sağlamaktadır (Heyward ve McCreary, 1977; Ng ve Fan, 2001; Sartorio ve ark., 2002; Chang ve ark., 2010; Massy-Westropp ve ark., 2011).

Yaşam kalitesinin ve yaşa bağlı kastaki değişikliklerin bir göstergesi olarak el kavrama kuvvetini ölçmek daha kolay, ekonomik ve hızlı bir yol olarak bildirilmiştir. Ayrıca kas kuvvetini ölçerek bireylerin ihtiyaç duyduğu antrenman modellerinin belirlenmesi sağlanabilmektedir. Bu bağlamda, nöromüsküler fonksiyonu iyileştirmek ve kas kütlesini arttırmak için dayanıklılık antrenmanlarına göre daha etkili olan kuvvet antrenmanlarından fayda sağlayabilecek olan bireylerin belirlenmesi ve yaşa bağlı olarak gelişen kuvvet kaybının geriye döndürülmesi önemlidir (Landers ve ark., 2001; Newman ve ark., 2006; Liu ve Latham, 2009; Hairi ve ark., 2010). Bu nedenle özellikle yaşlilarda el kavrama kuvvetine dair referans değerler dikkate alınarak ve el kavrama kuvvetini etkileyen faktörlerin belirlenmesi önemlidir. Bu araştırmanın da amacı 60 yaş üzeri bireylerde el kavrama kuvvetini ölçmek ve yağsız vücut kütlesi, cinsiyet, yaş gibi faktörlerin el kavrama el kavrama kuvveti üzerine etkisini incelemektir.

\section{YÖNTEM}

Araştırmaya Dünya Sağlık Örgütü (WHO) tarafından yaşlı olarak sınıflandırılan 60 - 80 yaş aralığındaki, yaşlarına göre eşleştirilmiş 50 kadın, 50 erkek toplam 100 kişi gönüllü olarak katılmıştır (WHO, 2015). Araştırmaya katılan gönüllülerde boy uzunluğu (cm), vücut ağırlığ $(\mathrm{kg})$, vücut kütle indeksi $\left(\mathrm{kg} / \mathrm{m}^{2}\right)$, yağ yüzdesi, yağsız vücut kütlesi ve el kavrama kuvveti değerleri ölçülmüştür.

\section{Boy Uzunluğu Ölçümü}

Katılımcıların ağırlığı iki eşit ayağına dağılmış şekilde topuklar birleşik ve baş Frankfort planda kollar omuzlardan serbestçe yanlara sarkıtılmış durumdayken stadiometre ile ölçülmüştür. Katılımcılardan tek ölçüm alınmıştır.

\section{Vücut Ăğırlı̆̆ı ve Vücut Yă̆ Yüzdesi Ölçümü}

Gönüllülerin vücut ağırlığ 1 ve vücut yăg yüzdesini belirlemek üzere bioelektrik impedans ölçüm cihazı (Tanita Body Composition Analyzer Type SC-330) kullanılmıştır. Gönüllülerin iki ayağının tartıya eşit basması sağlanarak dik ve hareketsiz durumdayken ölçümleri alınmıştır. Gönüllülere test öncesi ölçüm prosedürleri hakkında bilgi verilmiş ve son 24 saat şiddetli egzersiz ve alkol tüketiminden kaçınılması, son 4 saat kafein ve son 2 saat herhangi bir besin alınmaması istenmiştir (Kyle ve ark., 2004).

\section{Vücut Kütle Indeksi}

VKİ= Ağırlık $(\mathrm{kg}) /$ Boy $\left(\mathrm{m}^{2}\right)$ formülü kullanılarak hesaplanmıştır.

\section{El Kavrama Kuvveti (EKK) Ölçümü}

Katılımcıların EKK ölçümü için, 5.0-100.0 kg aralığında ve $0.1 \mathrm{~kg}$ hassasiyetinde ölçüm yapabilen ve ayarlanabilir kavrama kolu olan dijital el dinamometresi (Takei A5401, Japonya) kullanılmıştır. Ölçümler sırasında, katılımcılardan ayaklar omuz genişliğinde açık, ayakta duruş pozisyonunda, dirsek tam ekstansiyondayken karşıya bakmaları söylenmiştir. Ölçüm yapılmadan önce dinamometre katılımcıların el boyutlarına göre ayarlanmıştır. Dinamometrenin işaret parmağında 90 derecelik fleksiyon olacak şekilde, elde rahat tutuş pozisyonunda (fleksiyon ve ekstansiyon halinde değil) tutulması söylenmiştir. Katılımcılara 
tutamağı tüm güçleriyle 3 saniye boyunca sıkmaları söylenmiştir. Test sırasında nefeslerini tutmamaları ve dinamometreyi sallamamalarına dair bilgi verilmiştir. Dominant elin belirlenmesi için katılımcılardan yemek yerken veya yazarken hangi ellerini kullandıkları öğrenilmiştir. Katılımcıların dominant elden kavrama kuvveti ölçümleri üç kez alınmış ve en yüksek değer kilogram $(\mathrm{kg})$ cinsinden, istatistiksel olarak değerlendirilmek üzere alınmıştır. Her deneme arasında en az 60 saniye ara verilmiştir (Kim ve ark., 2018). Ayrıca EKK üzerine yağsız vücut ağırlığının etkisini standardize etmek için, EKK değerleri yağsız kas kütlesine bölünerek rölatif el kavrama kuvveti (REKK) değerleri hesaplanmıştır. Değerler dominant (D) ve dominant olmayan (ND) el olarak sınıflandırılmıştır.

\section{Istatistiksel Analiz}

Araştırma örneklem büyüklügünün belirlenmesi için 1. tip hataya ilişkin anlamlılık düzeyi 0.05, etki büyüklüğü 0.50 ve güç 0.80 olarak alınmış ve GPower 3.1 yazılımı kullanılmıştır. $\mathrm{Bu}$ doğrultuda Rothenberg ve ark. (Rothenberg ve ark., 2015) araştırma sonuçları dikkate alınarak yapılan güç analizine göre araştırma örneklem büyüklüğü 100 kişiden oluşturulmuştur. Elde edilen verilerin basıklık ve çarpıklık değerleri (Tabachnick ve Fidell, 2007), histogram, normal Q-Q ve kutu grafiklerinin görsel değerlendirmesi ve Shapiro-Wilk testi (Shapiro ve Wilk, 1965) sonrasında verilerin normal dağıldığ 1 tespit edilmiştir. Verilerin dağılımı incelendikten sonra gruplar arasındaki ilişki düzeylerini değerlendirmek için Pearson Korelasyon testi, değişkenlerin EKK üzerine etki düzeylerini belirlemek için basit doğrusal regresyon analizi kullanılmıştır. Cinsiyete göre kıyaslamaları değerlendirmek için ise Bağımsız Örneklem TTesti kullanılmıştır. Verilerin analizinde SPSS v.23 paket programı kullanılmış ve istatistiksel anlamlılık düzeyi olarak $\mathrm{p}<0.05$ değeri dikkate alınmıştır.

\section{BULGULAR}

Araştırmaya katılan gönüllülerin demografik değişkenleri Tablo 1'de gösterilmiştir. Kadın ve erkeklerin her ne kadar VKİ değerleri benzer olsa da, yağ yüzdesinin kadınlarda istatistiksel açıdan yüksek olduğu tespit edilmiştir.

Tablo 1. Demografik değişkenler

\begin{tabular}{lcccc}
\hline Değişkenler & $\begin{array}{c}\text { Kadın (n:50) } \\
\text { Ort } \pm \text { SS }\end{array}$ & $\begin{array}{c}\text { Erkek (n:50) } \\
\text { Ort } \pm \text { SS }\end{array}$ & $\mathrm{t}$ & $\mathrm{p}$ \\
\hline Yaş (yıl) & $67.34 \pm 3.99$ & $67.2 \pm 3.93$ & 0.071 & 0.943 \\
Boy Uzunluğu $(\mathrm{cm})$ & $157.4 \pm 5.6$ & $170.4 \pm 6.8$ & -10.432 & 0.000 \\
VA $(\mathrm{kg})$ & $65.7 \pm 8.6$ & $75.0 \pm 11.0$ & -4.693 & 0.000 \\
VKI $\left(\mathrm{kg} / \mathrm{m}^{2}\right)$ & $26.5 \pm 3.5$ & $26.0 \pm 3.6$ & 0.680 & 0.498 \\
VYY $(\%)$ & $34.9 \pm 5.9$ & $23.1 \pm 6.5$ & 9.461 & 0.000 \\
YVK $(\mathrm{kg})$ & $42.6 \pm 3.2$ & $57.3 \pm 7.2$ & -13.161 & 0.000 \\
\hline
\end{tabular}

Ort $\pm \mathrm{SS}=$ Ortalama \pm standart sapma; VA= Vücut ağırlığı; VKİ= Vücut kütle indeksi; VYY= Vücut yağ yüzdesi; YVK= Yağsız vücut kütlesi.

Kadınların her iki elleri için EKK değerleri beklenildiği üzere erkeklerden düşük çıkmıştır. Bununla birlikte yağsız vücut kütlesi başına düşen el kavrama kuvveti değerlendirildiğinde yine aynı şekilde kadınların istatistiksel olarak daha düşük REKK değerlerine sahip olduğu tespit edilmiştir (Tablo 2). 
Tablo 2. El kavrama kuvveti değerleri

\begin{tabular}{lcccc}
\hline Değişkenler & $\begin{array}{c}\text { Kadın (n:50) } \\
\text { Ort } \pm \text { SS }\end{array}$ & $\begin{array}{c}\text { Erkek (n:50) } \\
\text { Ort } \pm \text { SS }\end{array}$ & t & p \\
\hline D EKK $(\mathrm{kg})$ & $21.5 \pm 3.2$ & $33.6 \pm 7.3$ & -10.767 & 0.000 \\
$\operatorname{ND~EKK~}(\mathrm{kg})$ & $20.3 \pm 3.5$ & $32.5 \pm 7.5$ & -10.463 & 0.000 \\
D REKK $(\mathrm{kg} / \mathrm{kg})$ & $0.51 \pm 0.09$ & $0.59 \pm 0.11$ & -3.616 & 0.000 \\
ND REKK $(\mathrm{kg} / \mathrm{kg})$ & $0.48 \pm 0.09$ & $0.57 \pm 0.11$ & -4.170 & 0.000
\end{tabular}

Ort $\pm \mathrm{SS}=$ Ortalama \pm standart sapma; D EKK= Dominant el kavrama kuvveti; ND EKK= Dominant olmayan el kavrama kuvveti; D REKK= Dominant rölatif el kavrama kuvveti; ND REKK= Dominant olmayan rölatif el kavrama kuvveti

Gönüllülerin EKK kuvveti ile demografik değişkenleri arasındaki ilişki Tablo 3.'de gösterilmiştir.

Tablo 3. EKK ve demografik veriler arasındaki ilişki

\begin{tabular}{|c|c|c|c|c|c|c|c|c|c|}
\hline \multicolumn{2}{|c|}{$\begin{array}{c}\text { Pearson K.K. } \\
(\mathrm{n}=100)\end{array}$} & (2) & (3) & (4) & (5) & (6) & (7) & (8) & (9) \\
\hline Yaş & (1) & -.075 & .052 & .144 & -.039 & -.169 & -.185 & -.188 & -.223 \\
\hline Boy & (2) & 1 & $.493^{\mathrm{c}}$ & $-.636^{\mathrm{c}}$ & $.825^{\mathrm{c}}$ & $.656^{\mathrm{c}}$ & $.685^{\mathrm{c}}$ & $.221^{\mathrm{a}}$ & $.331^{\mathrm{c}}$ \\
\hline VA & (3) & & 1 & .119 & $.747^{\mathrm{c}}$ & $.456^{\mathrm{c}}$ & $.437^{\mathrm{c}}$ & -.025 & -.017 \\
\hline VYY & (4) & & & 1 & $-.546^{c}$ & $-.553^{c}$ & $-.592^{c}$ & $-.297^{\mathrm{b}}$ & $-.415^{\mathrm{c}}$ \\
\hline YVK & (5) & & & & 1 & $.752^{\mathrm{c}}$ & $.760^{\mathrm{c}}$ & $.205^{\mathrm{a}}$ & $.290^{\mathrm{b}}$ \\
\hline D EKK & (6) & & & & & 1 & $.935^{\mathrm{c}}$ & $.764^{\mathrm{c}}$ & $.723^{c}$ \\
\hline ND EKK & (7) & & & & & & 1 & $.645^{\mathrm{c}}$ & $.810^{\mathrm{c}}$ \\
\hline D REKK & (8) & & & & & & & 1 & .826 \\
\hline ND REKK & (9) & & & & & & & & 1 \\
\hline
\end{tabular}

Araştırma sonuçlarımıza göre 60-80 yaş aralığındaki bireylerde EKK ile yaş arasında istatistiksel açıdan anlamlı bir ilişki bulunmazken, YVK ile pozitif yönde yüksek ilişki bulunmuştur. Bununla birlikte YVK kontrol altına alındığında yaş ile EKK arasında zayıf fakat istatistiksel açıdan anlamlı negatif korelasyon bulunmuştur $(-0.239, \mathrm{p}=0.017 ;-0.212, \mathrm{p}=0.035$, sol ve sağ EKK için sırasıyla). Yaşa bağlı ve YVK'ne bağlı olarak EKK değişiklikleri Grafik 1 ve 2'de gösterilmiştir. Ayrıca yaş ve cinsiyet kontrol altına alındığında YVK ile EKK arasındaki korelasyona bakıldığında pozitif önde ilişki tespit edilmiştir $(0.436, p=0.000 ; 0.402, p=0.000$, sol ve sağ EKK için sırasıyla). 


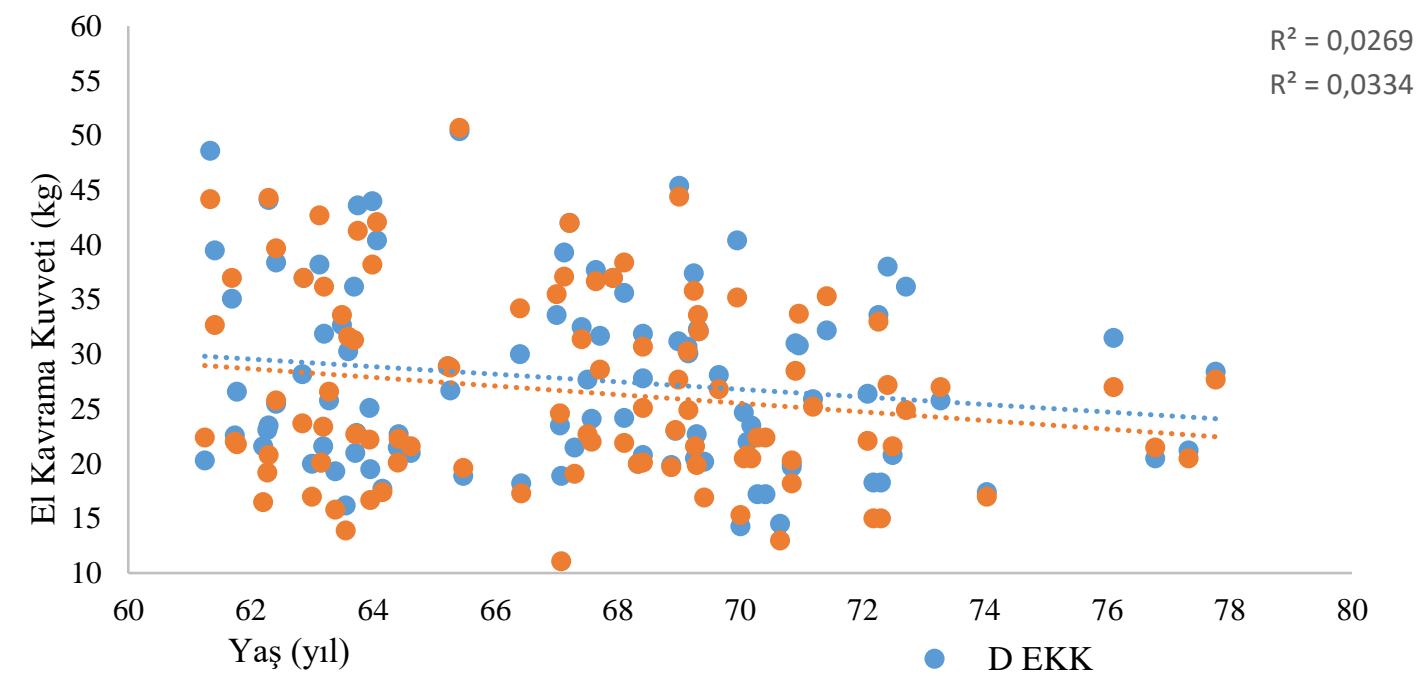

Grafik 1. EKK ve yaş ilişkisi

EKK üzerine etki eden değişkenler incelendiğinde yaşın sağ ve sol el için EKK'nin \% 0.020.03'ünü, YVK'nin sağ ve sol el için EKK'nin \%57-58'ini açıkladığı tespit edilmiştir.

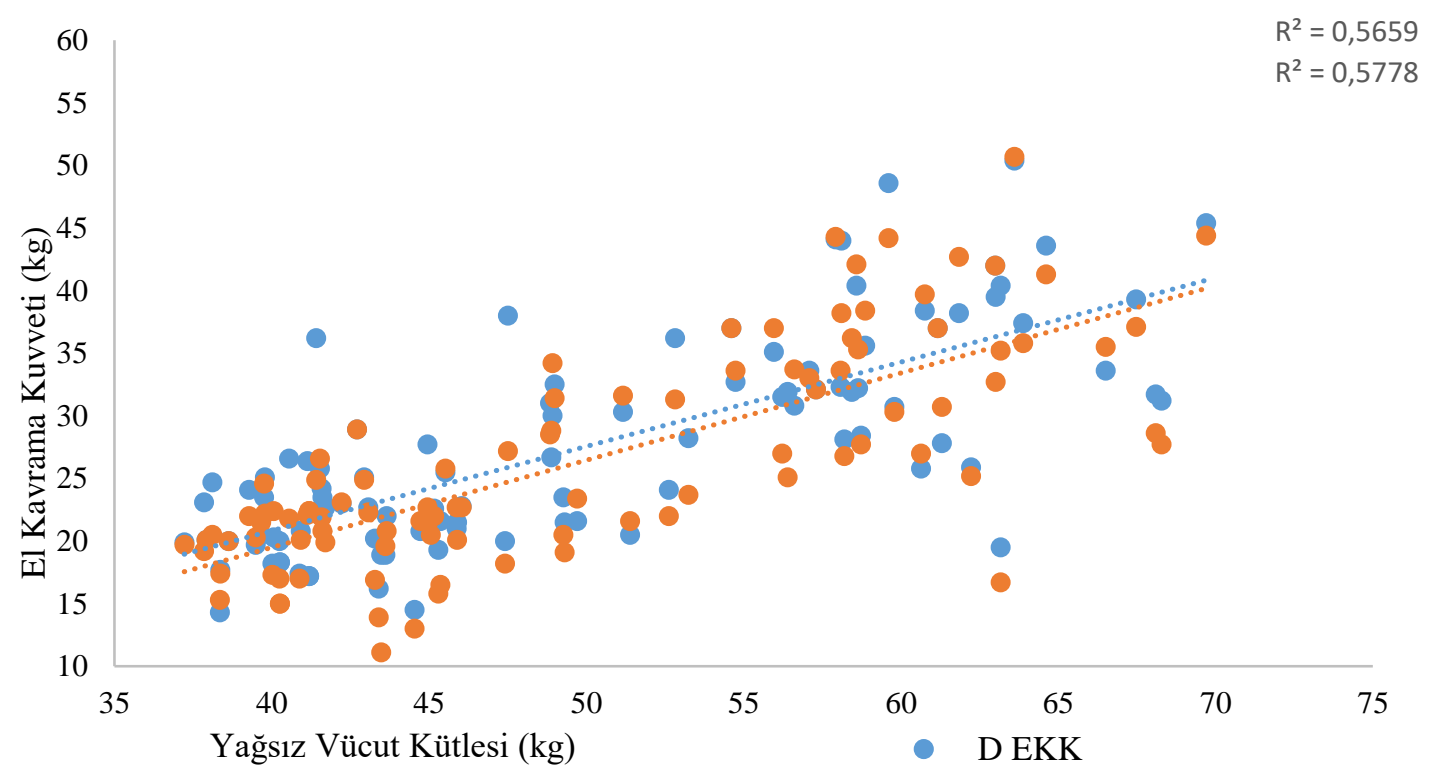

Grafik 2. EKK ve YVK ilişsisi

\section{TARTIŞMA VE SONUÇ}

$\mathrm{Bu}$ araştırmanın amacı 60 yaş üzeri bireylerde genel kuvvetin önemli bir göstergesi olan el kavrama kuvvetinin yaş, cinsiyet ve yağsız vücut kütlesine bağlı olarak değişimini incelemektir. Araştırma bulguları sonucunda kadınların erkeklere göre beklenildiği üzere daha düşük el kavrama kuvvetine sahip oldukları tespit edilmiştir. Bununla birlikte yağsız kas kütlesi dikkate alınarak değerlendirilen rölatif el kavrama kuvvetinin kadınlarda yine erkeklere göre anlamlı düzeyde düşük olduğu gözlemlenmiştir. Yaşa bağlı olarak EKK'nin değişimi incelendiğinde 
ise anlamlı bir ilişki tespit edilememiştir. Araştırmamıza katılan 60-80 yaş aralığında bireylerde EKK'ni etkileyen en büyük unsur olarak yaş değil yağsız vücut kütlesi olduğu tespit edilmiştir. Sarkopeni yaşlanmayla birlikte yağsız vücut kütlesinin azalmasıdır ve fiziksel kısıtlılığın oluşumunda önemli role sahiptir. Bununla birlikte yaşlanmayla birlikte kas kuvvetindeki kayıpların, kas kütlesinden çok daha fazla olduğu bildirilmiştir. Bu nedenle adipoz doku fonksiyonel kapasite kaybı için anahtar rol oynamaktadır. Ayrıca, kas kuvveti değerlendirilirken bu antropometrik özelliklerin dikkate alınması gerektiği bildirilmiştir. $\mathrm{Bu}$ nedenle özellikle referans değerlerin oluşturulmasında rölatif kuvvet değerlerinin kullanılması önerilmiştir (Estrada ve ark., 2007; Choquette ve ark., 2010; Lawman ve ark., 2016).

Araştırmamızda kadın ve erkeklerin el kavrama kuvvetleri salt ve yağsız vücut kütlesine göre rölatif olarak değerlendirilmiştir. REKK değerleri incelendiğinde kadınların erkeklere oranla istatistiksel açıdan anlamlı düzeyde düşük değerlere sahip olduğu tespit edilmiştir. Bu sonuç kadınların kas kütlesi kaybıyla birlikte, erkeklerle kıyaslandığında, nispeten daha fazla fonksiyonel özellik kaybı yaşadığını göstermektedir.

Araştırmamızda elde edilen EKK değerlerine bakıldığında literatürdeki verilerle benzerlik gösterdiği görülmüştür. Erkekler ve kadınların dominant el için kavrama kuvveti ortalamaları sırasıyla, 33.6 ve 21.5 kg olarak ölçülmüştür. Budziareck ve ark. Budziareck ve ark. (2008) 60 yaş ve üzeri erkek ve kadınlarda EKK değerini dominant el için sırasıyla 31.3 ve $19.1 \mathrm{~kg}$ olarak bildirmişlerdir. Araştırmalarında EKK değeri için sağlıklı olan sınır seviyesini erkekler için 18 $\mathrm{kg}$ ve kadınlar için $10 \mathrm{~kg}$ olarak bildirmişlerdir. Rodriguez-Garcia ve ark. (2017) benzer şekilde 60 yaş üzerindeki referans EKK değerlerini erkekler için $33 \mathrm{~kg}$, kadınlar için $22 \mathrm{~kg}$ olarak bildirmiştir. Günther ve ark.(2008) ise Kafkas bireylerde yaptıkları çalışmalarında referans değerleri; erkeklerde 60-69 yaş için $45 \mathrm{~kg}$, 70-79 yaş için $38 \mathrm{~kg}$ ve kadınlarda 60-69 yaş için 26 $\mathrm{kg}, 70-79$ yaş için $21 \mathrm{~kg}$ olarak bildirmişlerdir.

EKK genel kuvvetin ve sağlığın bir göstergesi olarak kabul edilmektedir. Bu nedenle ileriye yönelik hastalık, yaşam kalitesi ve yaralanma risklerinin öngörülmesinde kullanılmaktadır. Örneğin Rantanen ve ark. (1999) çalışmalarında; 45-68 yaş arası sağlıklı erkeklerde el kavrama kuvvetinin 25 yıl sonraki sakatlık ve fonksiyonel sinırlılıkların öngörülmesinde önemli olduğunu vurgulamıştır. Başka araştırmalarda da yaşlanmayla birlikte kas kütlesi ve kuvvetindeki azalma metabolik ve kardiyovasküler fonksiyon kaybı ilişkilendirilmiştir. Metter ve ark. (2002) 60 yaş üzerindeki erkeklerde yaşa bağlı olarak kas kütlesi ve kuvvette kayıplar olduğunu bildirmişlerdir. Ayrıca sarkopeninin yaşlılarda artan kırık riski, fonksiyonel kısıtlılık ve yaşlanmaya bağlı hastalıklar ile ilişkili olduğunu rapor etmişlerdir. Yapılan başka bir araştırmada 50 yaşın üzerindeki bireylerde yağsız vücut kütlesinde yılda \%1-2 ve kas kuvvetinde yılda \%1.5-5 azalma rapor edilmiştir (Keller ve Engelhardt, 2013). Ayrica kaslardaki zayıflamanın ölüm riskini arttırdığı bildirilmiştir (Metter ve ark., 2002; Goodpaster ve ark., 2006). Bu nedenle yaşa bağlı sarkopeniyi kısmen geri döndürmek için yaşlılarda kuvvet antrenmanlarının etkilerine yönelik birçok araştırma bulunmaktadır. Yaşlılarda kuvvet antrenmanlarıyla kas kütlesi ve kuvvetinin artışı hedeflenmektedir. Bununla birlikte kas hacmi ve kuvvetini etkileyen cinsiyet, hastalıklar, genetik gibi başka faktörlerin olduğu da bilinmektedir (Chen ve ark., 2013). Örneğin yaşlilarda kuvvet antrenmanlarına verilen fizyolojik cevapların cinsiyete göre farklılık gösterebileceği rapor edilmiştir. Özellikle hipertrofik tepki için cinsiyet farklılıklarının olduğu bildirilmiştir. Örneğin Ivey ve ark. (2000) yaşlılar üzerine yaptıkları çalışmalarında kuvvet antrenmanları sonrası erkeklerde hipertrofi artışı tespit etmişken, kadınların kas hacminde bir değişiklik olmadığını tespit etmişlerdir. Benzer şekilde Tracy ve ark. (1999) 65 yaş üstü bireylere yaptırılan kuvvet antrenmanları sonrasında erkeklerde kadınlara göre daha fazla kas hacmi ve kuvvet artışı rapor etmişlerdir. 
Benzer şekilde araştırmamızda da YVK erkeklerde kadınlara göre istatistiksel açıdan anlamlı olarak daha yüksek çıkmıştır.

Yaşlanmayla birlikte kas kütlesindeki kayıpla birlikte kuvvetin azaldığı bildirilmiş olsa da yaşa bağlı olarak kas kütlesi ve kuvvetindeki bu azalmayı tam olarak açıklayabilecek tek teori yoktur. Kas kuvvetini etkileyen fiziksel aktivite düzeyi, cinsiyet, genetik faktörler, hastalıklar gibi etkenler bireyler arasında yaşlanmaya bağlı kuvvet kaybına dair farklılıklar gösterebilmektedir. Yaşlanma süreçlerinin kuvvetteki azalmanın \%30-40'ından sorumlu olduğu, geri kalan kısmının ise günlük aktivite düzeyindeki azalma, beslenme veya kronik hastalıklar ile açıklanabileceği bildirilmiştir (Rantanen ve ark., 1997; Metter ve ark., 2002). Her ne kadar kas kuvvetiyle kas kütlesi arasındaki pozitif ilişki olduğuna dair araştırma sonuçları olsa da, özellikle yaşlılarda yüksek kas kütlesinin daha fazla kas kuvvetine yol açıp açmadığ1 net değildir. Örneğin Raue ve ark. (2009) 80 yaş üzerindeki kadınlarda kuvvet antrenmanlarıyla birlikte kas kütlesi artmamasına rağmen kuvvet artışı tespit etmişlerdir. Bununla birlikte, Chen ve ark. (2013) yaşlılarda kas kütlesinin ve kas kuvveti arasında pozitif yönde ilişki bulmuş ve kas kütlesinin kuvvet değişikliklerinin \%13’ünü açıkladığını bildirmişlerdir.

Araştırmamızda da 60-80 yaş aralığındaki bireylerde EKK ile yaş arasında negatif yönde çok zayıf ama istatistiksel açıdan anlamlı olmayan bir ilişki bulunmuşken, YVK ile pozitif yönde yüksek ilişki bulunmuştur ( $\mathrm{p}<0.001)$. Benzer şekilde araştırmacılar (Sartorio ve ark., 2002; Koopman ve van Loon, 2009; Aagaard ve ark., 2010; Mayer ve ark., 2011) yaşa bağlı olarak artan EKK'nin, artan kas kütlesiyle alakalı olduğunu rapor etmiştir. Bununla birlikte YVK kontrol altına alındığında yaş ile EKK arasında zayıf fakat istatistiksel açıdan anlamlı negatif korelasyon tespit edilmiştir. Araştırma sonuçlarımıza göre literatüre benzer şekilde, yaşlılarda kuvveti etkileyen ana unsurun YVK olduğu görülmektedir. Landers ve ark. (2001) genç ve yaşl1 kadınların kas kütlesini ve kuvvetlerini kıyasladıkları çalışmalarında; yaş ile kuvvet arasında negatif korelasyon bildirmişlerdir. Bununla birlikte yağsız kol kütlesi kontrol altına alındığında yaş ve dirsek fleksörleri arasında anlamlı bir ilişki tespit edememişlerdir. Özellikle kol bölgesindeki kuvvet kaybının kas kütlesinin azalmasına bağlı olduğunu bildirmişlerdir.

Araştırma sonuçlarımıza göre yaşlılarda ölüm riskini arttıran faktör olarak görülen kuvvet azalmasının, kas kütlesi kaybıyla ilişkili olabileceği düşünülmektedir. Bu nedenle kas kütlesini arttıracak antrenmanların yaşlıların yaşam kalitesine ve genel sağlık durumlarına olumlu etkileri olacağı düşünülmektedir. Fakat ilerleyen yaşla birlikte özellikle hipertrofi cevabının azalacağına dair araştırma sonuçları bulunmaktadır. Raue ve ark. (2009) kas kütlesini arttırmak için bireylerin altmışlı yaşlarında kuvvet antrenmanlarına katılmalarının ileriye yönelik bir avantaj sağlayabileceğini, seksenli yaşlarda ise kuvvet antrenmanlarıyla hipertrofi oluşturmanın oldukça zor olduğunu bildirmişlerdir. Kuvvet antrenmanlarıyla kazanılan kas kütlesi ve kuvvetinin ileriye yönelik olarak koruyucu etkileri olduğu bilinmektedir ve bu etkiden faydalanmak için yaşlılarda mümkün olduğunca erken dönemde kas kütlesini arttırmaya yönelik önlemlerin alınması gerekmektedir. Araştırmalar (Mcdermott ve Mernitz, 2006; Liu ve Latham, 2009) uygun şiddet, yöntem ve sıklıkta yapılan kuvvet antrenmanlarının yaşlılarda yaşam kalitesini arttırdığını ve fonksiyonel kısıtlılıklarını azalttığını belirtmektedirler.

Araştırmamızda 60-80 yaş aralığındaki bireylerde EKK kuvveti üzerine yaşın istatistiksel açıdan anlamlı etkisinin olmadığını, bununla birlikte yağsız vücut kütlesi ile EKK arasında anlamlı olarak yüksek korelasyon olduğu tespit edilmiştir. Ayrıca kadınların EKK değerleri erkeklere göre daha düşük bulunmuştur. Bununla birlikte yağsız vücut kütlesine göre EKK değerleri rölatif olarak değerlendirildiğinde kadınların EKK değerlerinin yine erkeklerden anlamlı olarak düşük olduğu tespit edilmiştir. Bu durum; kadınlarda kuvvetin azalmasının sadece daha düşük kas kütlesinden kaynaklanmadığını, fonksiyonel olarak da birim kasın 
kuvvet üretme yeteneğinde azalmalar olduğunu göstermektedir. Bu nedenle özellikle kadınlarda kuvvet kaybına neden olan diğer faktörlerin araştırılması ve kuvvetin korunmasına yönelik önlemler alınması önemlidir.

\section{KAYNAKLAR}

Aagaard, P., Suetta, C., Caserotti, P., Magnusson, S. P., Kjær, M. (2010). Role of the nervous system in sarcopenia and muscle atrophy with aging: Strength training as a countermeasure. Scand J Med Sci Sports, 20 (1), 49-64.

Budziareck, M. B., Duarte, R. R. P., \& Barbosa-Silva, M. C. G. (2008). Reference values and determinants for handgrip strength in healthy subjects. Clinical Nutrition, 27 (3), 357-362.

Chang, H. Y., Chou, K. Y., Lin, J. J., Lin, C. F., Wang, C. H. (2010). Immediate effect of forearm kinesio taping on maximal grip strength and force sense in healthy collegiate athletes. Phys Ther Sport, 11 (4), 122-127.

Chen, L., Nelson, D. R., Zhao, Y., Cui, Z., \& Johnston, J. A. (2013).Relationship between muscle mass and muscle strength, and the impact of comorbidities: A population-based, cross-sectional study of older adults in the united states. BMC Geriatrics, 13 (1), 74.

Choquette, S., Bouchard, D., Doyon, C., Sénéchal, M., Brochu, M., Dionne, I. (2010). Relative strength as a determinant of mobility in elders 67-84 years of age. A nuage study: Nutrition as a determinant of successful aging. J Nutr Health Aging, 14 (3), 190-195.

Estrada, M., Kleppinger, A., Judge, J. O., Walsh, S. J., Kuchel, G. A. (2007). Functional impact of relative versus absolute sarcopenia in healthy older women. J Am Geriatr Soc, 55 (11), 1712-1719.

Goodpaster, B. H., Park, S. W., Harris, T. B., Kritchevsky, S. B., Nevitt, M., Schwartz, A. V., Newman, A. B. (2006). The loss of skeletal muscle strength, mass, and quality in older adults: The health, aging and body composition study. J Gerontol A Biol, 61 (10), 1059-1064.

Günther, C. M., Bürger, A., Rickert, M., Crispin, A., Schulz, C. (2008). Grip strength in healthy caucasian adults: Reference values, J Hand Surg Am, 33 (4), 558-565.

Hairi, N. N., Cumming, R. G., Naganathan, V., Handelsman, D. J., Le Couteur, D. G., Creasey, H., Sambrook, P. N. (2010). Loss of muscle strength, mass (sarcopenia), and quality (specific force) and its relationship with functional limitation and physical disability: The concord health and ageing in men project. J Am Geriatr Soc., 58 (11), 2055-2062.

Heyward, V., McCreary, L. (1977). Analysis of the static strength and relative endurance of women athletes. Research Quarterly, 48 (4), 703-710.

Ivey, F. M., Roth, S. M., Ferrell, R. E., Tracy, B. L., Lemmer, J. T., Hurlbut, D. E., Metter, E. J. (2000). Effects of age, gender, and myostatin genotype on the hypertrophic response to heavy resistance strength training. $J$ Gerontol Series, 55 (11), M641-M648.

Karan, A. (2006). Yaşl1lıkta egzersiz ve spor. Türk Fiz Tip Rehab Derg. (52), 53-56.

Keller, K., Engelhardt, M. (2013). Strength and muscle mass loss with aging process. Age and strength loss. Muscles Ligaments Tendons, 3 (4), 346.

Kim, C. R., Jeon, Y.J., Kim, M. C., Jeong, T., Koo, W. R. (2018). Reference values for hand grip strength in the south korean population. PloS one. 13 (4), e0195485.

Koopman, R., Van Loon, L. J. (2009)Aging, exercise, and muscle protein metabolism. J Appl Physiol, 106 (6), 2040-2048.

Kyle, U. G., Bosaeus, I., De Lorenzo, A. D., Deurenberg, P., Elia, M., Gómez, J. M., Pirlich, M. (2004). Bioelectrical impedance analysis - part ii: Utilization in clinical practice. Clinical nutrition, 23 (6), 1430-1453. 
Landers, K. A., Hunter, G. R., Wetzstein, C. J., Bamman, M. M., Weinsier, R. L. (2001). The interrelationship among muscle mass, strength, and the ability to perform physical tasks of daily living in younger and older women. J Gerontol A Biol, 56 (10), B443-B448.

Lawman, H. G., Troiano, R. P., Perna, F. M., Wang, C.-Y., Fryar, C. D., Ogden, C. L. (2016). Associations of relative handgrip strength and cardiovascular disease biomarkers in us adults, 2011-2012. Am J Prevent Med, 50 (6): 677-683.

Liu, C. J., Latham, N. K. (2009). Progressive resistance strength training for improving physical function in older adults. Cochrane, (3), CD002759.

Massy-Westropp, N. M., Gill, T. K., Taylor, A. W., Bohannon, R. W., Hill, C. L. (2011). Hand grip strength: Age and gender stratified normative data in a population-based study. BMC Res Notes, 4, 127.

Mayer, F., Scharhag-Rosenberger, F., Carlsohn, A., Cassel, M., Müller, S., Scharhag, J. (2011). The intensity and effects of strength training in the elderly. Deutsches Ärzt Int., 108 (21), 359.

Mcdermott, A. Y., Mernitz, H. (2006). Exercise and older patients: Prescribing guidelines. Am Fam Physician, 74 (3).

Metter, E. J., Talbot, L. A., Schrager, M., Conwit, R. (2002). Skeletal muscle strength as a predictor of all-cause mortality in healthy men. J Gerontol A Biol. 57 (10), B359-B365.

Musalek, C., Kirchengast, S. (2017). Grip strength as an indicator of health-related quality of life in old age-A pilot study. Int J Environ Res Public Health, 14 (12), 1447.

Newman, A. B., Kupelian, V., Visser, M., Simonsick, E. M., Goodpaster, B. H., Kritchevsky, S. B., Harris, T. B. (2006). Strength, but not muscle mass, is associated with mortality in the health, aging and body composition study cohort. J Gerontol A Biol, 61 (1), 72-77.

Ng, G. Y., Fan, A. C. (2001). Does elbow position affect strength and reproducibility of power grip measurements? Physiotherapy, 87 (2), 68-72.

Rantanen, T., Era, P., Heikkinen, E. (1997). Physical activity and the changes in maximal isometric strength in men and women from the age of 75 to 80 years. J Am Geriatr Soc., 45 (12), 1439-1445.

Rantanen, T., Guralnik, J. M., Foley, D., Masaki, K., Leveille, S., Curb, J. D., White, L. (1999). Midlife hand grip strength as a predictor of old age disability. JAMA, 281 (6), 558-560.

Raue, U., Slivka, D., Minchev, K., Trappe, S. (2009). Improvements in whole muscle and myocellular function are limited with high-intensity resistance training in octogenarian women. J Appl Physiol, 106 (5), 1611-1617.

Rodríguez-García, W. D., García-Castañeda, L., Orea-Tejeda, A., Mendoza-Núñez, V., González-Islas, D. G., Santillán-Díaz, C., Castillo-Martínez, L. (2017). Handgrip strength: Reference values and its relationship with bioimpedance and anthropometric variables. Clin Nutr ESPEN, 19, 54-58.

Rothenberg, E., Dahlin-Ivanoff, S., Lindblad, A., Bosaeus, I. Body composition and hand grip strength in healthy community-dwelling older adults in sweden. J Aging Res Clin Prac, 4 (1), 54-58.

Sartorio, A., Lafortuna, C. L., Pogliaghi, S., Trecate, L. (2002). The impact of gender, body dimension and body composition on hand-grip strength in healthy children. J Endocrinol Invest, 25 (5), 431-435.

Shapiro, S. S., Wilk, M. B. (1965). An analysis of variance test for normality (complete samples). Biometrika, 52 (3/4), 591-611.

Tabachnick, B. G., Fidell, L. S. (2007). Using multivariate statistics: Allyn \& Bacon/Pearson Education.

Tracy, B., Ivey, F., Hurlbut, D., Martel, G., Lemmer, J., Siegel, E., Hurley, B. (1999). Muscle quality. Ii. Effects of strength training in 65-to 75-yr-old men and women. J Appl Physiol, 86 (1), 195-201. 
WHO. (2015). World report on ageing and health: World Health Organization.

Yıldırım, B., Özkahraman, Ş., Ersoy, S. (2012). Yaşlılıkta görülen fizyolojik değişiklikler ve hemşirelik bakımı. Düzce Üniversitesi Sağllk Bilimleri Enstitüsü Dergisi, 2 (2): 19-23. 